\title{
Application Systems Available In UNIMED Language Skills Text
}

\author{
Rabiah Adawi \\ Universitas Negeri Medan, Indonesia \\ rabiah.adawi@yahoo.co.id
}

\section{Abstract}

This study aims to describe the attitude appraisal system contained in the French thesis text at UNIMED. The method used in this study is a descriptive qualitative method. The research sample is the French thesis text at UNIMED on behalf of Ayokta Ghea M. Panjaitan, NIM. 21013001 where the type of thesis is linguistics with the title Analyze De Champ Lexical Des Activités Des Yeux En Français (Analysis of the Lexical Meaning of Eye Activity in French) totaling 58 pages with the highest GPA of 3.85 and Irna Fadillah Nasution, NIM. 2101131002 with a GPA of 3.45 with the title of the thesis Analyze Sémiotique De La Publicite Femme De Beauté Dans Le Magazine Femme Actuelle (Semiotic Analysis of Beauty Advertisements in the French Magazine Femme Actuelle) totaling 60 pages that have been validated by native speakers teaching at the French Language Education Study Program UNIMED in 2015 and also teaches at the Alliance Française $(A F)$ called Marine Petite. Data were analyzed using the Simple Concordance Program (SCP) concordance program software using the Apraisal system, namely: Attitude Apraisal. The results showed that the Apraisal System in the French Thesis text at UNIMED was the Paradigmatic System because the Apraisal System in the French thesis text consisted of (a). Gender (le gendre), which consists of: masculine (masculin) and feminine (féminin) and (b). Total (le nombre), which consists of: single (singulier) and plural (pluriel).

\section{Introduction}

Language is something that every member of the community has. It is used to convey meaning either in oral or written form. On the one hand, people think that language functions to send information. On the other hand, language becomes the power to dominate others. This happens if people understand how to use language as a medium to dominate others because language has meanings that are related to history, social and politics so that the language we produce is written, verbally or visually used to convey meaning that is identified socially, politically, and historically. Language is contextually related to the social context that influences the text's relationship with social life and is oriented to various aspects such as political, social, cultural, economic, religious and ideological. This study analyzes attitudes, graduations and positioning in French thesis text at UNIMED.

This research was conducted to determine the Paradigmatic System in French thesis text consisting of (a). Gender (le gendre), which consists of: masculine (masculin) and feminine (féminin) and (b). Total (le nombre), which consists of: single (singulier) and plural (pluriel).

Example of an Appraisal System in the UNIMED French thesis:

La langue possède un rôle important dans la vie humaine. 
(Language plays an important role in human life).

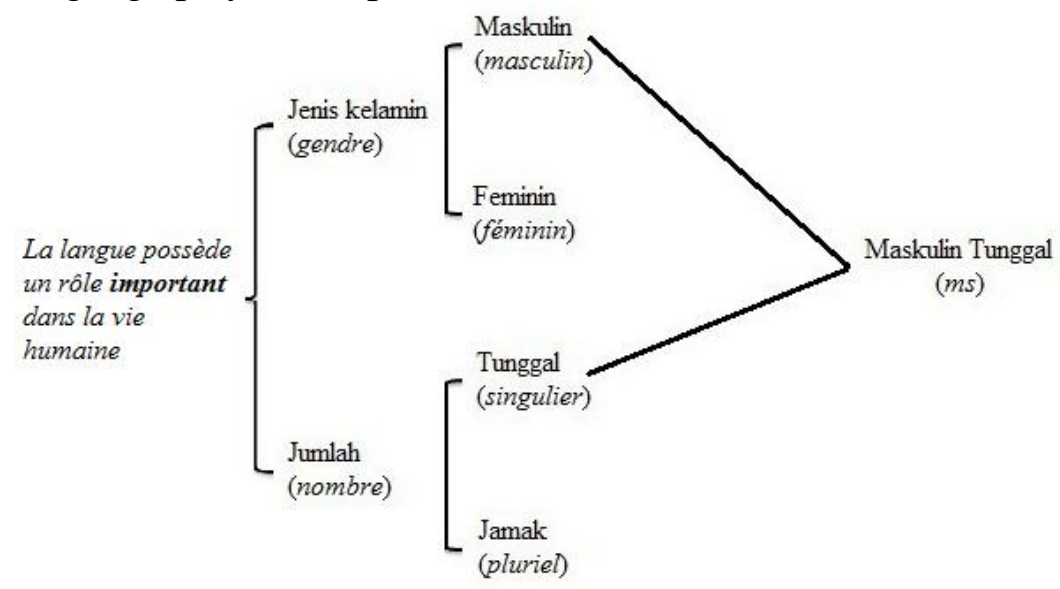

The appraisal system of the above sentence has a masculine gender (masculin) and a singular (nombre) number (singular). The researcher chose the research location at UNIMED because UNIMED has a French study program, a French thesis, native speaker and language laboratory facilities.

\section{Literature Review}

\subsection{Appraisal System}

According to Martin and White (2005: 13) paradigmatic relationships are traditionally displayed in a paradigm that describes one dimension to another (see figure 2.8). Halliday designed an image referred to as (system network), a network of systems for displaying paradigmatic relationships. The names of rows and columns in the paradigm are treated as features in the choice system, and any feature can be an input condition to another system. In Figure 2.8, a square bracket with an arrow pointing inwards constitutes a logic or relationship, saying that subjective modalities can be in the form of explicit or implicit.

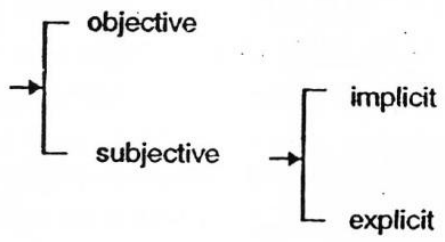

Figure 2. 8. Networks that display system dependent (Martin \& White, 2005)

Each of the two systems in Figure 2.8 is a binary system, but the system can contain a number of features. In general, these systems contain two or three, because usually to group features into smaller systems if a system with three or more features.

\subsection{Language Metaphysical}

Metaphysical language has 3 (three) components, namely ideational, interpersonal, and textual. Ideational sources relate to understanding from experience: what happens, including what someone does to who, where, when, why, and how the logic relationship occurs between one another. Interpersonal sources discuss social relations: how people interact, including feelings of sharing between them and textual sources discuss information flow: the way ideational and interpersonal meanings are spread in semiosis, including the 
interconnection between activities and language (actions, images, music, etc.) (Sinar 2012 : 27).

In the lexicogram, one unit of experience is realized in a clause consisting of three elements namely (1) process, (2) participants, and (3) circumumstan (Halliday 1985/1994, Halliday \& Matthiessen 2004, Martin 1992, Saragih 2006, and Sinar 2003 , 2008, Suriyadi 2014). The process is the activities / activities that occur in the clause. The participant is the person or object involved in the process and the circumstance is the environment in which the process involving participants occurs.

\subsection{Text and Discourse}

The term text is closely related to the study in this study. Text, according to Halliday and Hasan (1985: 10), is a functional language that is a language that performs certain tasks in certain contexts, and as a unit of language users. As a functional language unit in context, text is the use of language produced by people to convey the purpose of a meaningful message (Widdowson 2007: 6-8). If a language has meaning in a social context, the language unit is called text (Saragih 2006: 4). According to Halliday and Hasan (1985: 5), the path to an understanding of language lies in the study of texts. The text consists of meanings even though the text consists of words and sentences. Text is basically a unit of meaning. Text must be viewed from two angles simultaneously namely as a product and as a process because of its nature as a unit of meaning. As a product, text is an outcome, something that can be recorded and studied because it has a certain arrangement of texts and can be described in systematic terms. Text is also a process in the sense that text is formed through a process of choosing meaning continuously.

The concept of discourse according to Sinar (2012: 1), is often used to cover broad language phenomena, there are political discourse, political discourse, conjecture and conjecture, ademic discourse or academic discourse, lecture discourse or lecture discourse (Sinar, 2002), and there are many other discourses that refer to human social activities when discourse. The term discourse, according to Sinar (2012: 3), matters that are socially oriented, while the term text is used when the orientation of the discussion of the material form and structure of language. From the context in which the text is used, the term text refers to the language used, the term text refers to the language used rather than language as a system that has not yet been implemented. Discourse is a social phenomenon (Sinar 2012: 7).

Furthermore, Sinar (2012: 2) states that the nature of the discourse is not only the language of the barrel but wider scope to the forms of interpretation, interaction, types of speeches, genres, literary works, science, education, children's writing, communication in the classroom between teacher and student, between adults and children, children with children, adults and adults, language textbooks, translations, different registers, discussions or discussions, interviews, drama, TV programs Even the most recent multimodal discourse analysis approach focuses on semiotic codes such as images, films, symbols, comic strips, colors and various other visual aspects.

\subsection{Evaluation in Languages}

Evaluation according to Bednarek (2006), is defined as referring to the language expression of the opinions of speakers / writers with a number of dimensions and semantic parameters. Evaluation can relate to the assessment of entities / propositions, such as good or bad, important or not important, comprehensive or not comprehensive, may or may not be, sincere or not sincere, expected or cannot be expected and others (Bednarek 2006), including 
nosi affect (Besnier 1990), modality (Perkins 1983, Palmer 1995, Bybee \& Fleischman 1995, Coates 1983 and evidentiality (Chafe and Nichols 1986, Johanson and Utas 2000, Aikhenvald 2004).

The appraisal framework is an evaluative language theory, developed in the systemic functional linguistic tradition. The appraisal framework describes the taxonomy of the types of language used to link one's evaluation and position with respect to the evaluation of others (Read \& Carrol 2012).

The framework for opinion analysis in functional systemic linguistics was developed on behalf of Apraisal with three sub-categories: attitude, positioning, and graduation (see Macken-horaric and Martin 2003, Martin and rose 2003, Martin and White 2005) and there is also a statistical analysis based on the corpus (see Biber et al 1999, Conrad and Biber 2000).

\subsection{French Grammar}

According to Calvet et Chompret (2010) Valeur des désinences (Value of suffixes), les lettres ou les syllabes dont la désinence se compose d'indiquer selon les cas cas genres, le nombre, la personne des mots et dan ver le, le groupe, le temps et le mode. Letters or syllables that have a suffix have gender, number, type of word problems, and in verbs, groups, times, and modes.

\section{Le genre (Gender)}

According to Calvet et Chompret (2010, par genre d'un mot, on entend un caractère distinctif de ce mot, provenant de ce qu'il désigne un être mâle ou un être femelle. Il ya deux genres principaux: Le masculin, commun à tous les mots designant des êtres mâles: homme, chat; Le féminin, commun à tous les mots designant des êtres femelles: femme, chatte Des des raisons d'analogie, d'étymologie, d'homophonie, etc. On fait ranger dans 1 ' un ou l'autre groupe les noms d'êtres inanimés: char, charrette, Le latin avait un troisième genre, le neutre, Il n'en est resté en français que des traces dans les adjective et surtout dans les pronoms: l'utile , l'agréable, reproach, quoi, etc. Le neutre français se confond pour la forme et la construction avec le masculin Based on the sex of the word, we see the characteristics of a word, based on its sex, masculine or feminine. main gender of the noun: masculine, generally all nouns are masculin sex: homme, chat, feminine, generally all feminine nouns: femme, chatte. Based on reasons of analogy, reasons for etymology, homophones, and others. We can arrange in one or another group of inanimate nouns: char, charette. In Latin, the third sex is neutral. Neutral sex is only found in French, for example in adjectives, especially in pronouns: l'utile, l'agréable, cela, quoi, etc. The neutral sex mingles for form and construction with the masculine gender.

\section{Research Method}

The method used in this research is a qualitative descriptive method with the understanding that this study uses empirical data which is carried out as objectively as possible by conducting formal and functional tests. This method establishes the requirement that a study must be carried out on the basis of available facts, so that the description given about the object under study produces a description of language that can be compared with portraits, that is, depictions according to the actual situation. This method will underlie this research in data collections and analysis (Sumarsih 2009). 
Descriptive method has properties and characteristics that are considered very suitable to be used for this study. Description of grammatical and semantic categories of language evaluation is done through testing the form, meaning and relationship with the elements of the text or discourse obtained specifically from the corpus of language use in French thesis text at UNIMED. Through this method with the help of concordance software programs, research data can be captured that can be used to solve research problems and achieve predetermined research goals.

This study uses a corpus as a source of research data in the form of 2 French thesis texts at UNIMED on behalf of Ayokta Ghea M. Panjaitan, NIM. 21013001 with the highest GPA of 3.85 with the title of the thesis Analyze De Champ Lexical Des Activités Des Yeux En Français (Analysis of the Lexical Meaning of Eye Activity in French) totaling 58 pages and Irna Fadillah Nasution, NIM. 2101131002 with a GPA of 3.45 with the title of the thesis Analyze Sémiotique De La Publicite Femme De Beauté Dans Le Magazine Femme Actuelle (Semiotic Analysis of Beauty Advertisements in the French Magazine Femme Actuelle) totaling 60 pages that have been validated by native speakers teaching at the French Language Education Study Program UNIMED in 2015 and also teaches at the Alliance Française (AF) called Marine Petite.

Some of the reasons used as the basis for choosing the 2 French thesis texts above as data sources for this study are:

a. Easy access to data sources

b. Each data source can theoretically present the genre of language use in written text in the form of a different French thesis text

c. The written text in the form of French thesis text realizes interpersonal semantic resources in a different way from the oral text.

d. Each type of text in the data source above is assumed to utilize interpersonal semantic resources differently because the two French thesis texts above are assumed to realize different contextual situations in their language use.

e. These two different French thesis texts have never been examined together in terms of evaluative language.

\subsection{Data Collection Technique}

The data collection technique was carried out by collecting 2 French thesis texts at UNIMED. Then the Apraisal framework is used to find attitudes, positioning and graduations that show the characteristics of Apraisal in the French thesis text at UNIMED. Data collection uses data search techniques by collecting French thesis text data at UNIMED. Additionally web concordance tools provided by Webcorp on the internet are used to facilitate language analysis. After the data source for each group of text is obtained and recorded in a computer. This study uses the Simple Concordance Program (SCP) concordance software program to capture, classify each lexeme of French thesis text based on Apraisal theory, namely the Attitudes, Positioning and Graduation realms, gathering and then analyzing the data.

Each data obtained from the French thesis text at UNIMED will be identified and given a marker whether the texts are included in the categories of attitude, positioning, graduation (Suriyadi 2014). Then, each Apraisal sub-system is classified based on the expression whether the words or expressions have a category in the Apraisal sub-system.

After that, a statistical analysis is performed to see the characteristics of each text. This analysis includes analysis of lexical variations, lexical visibility, and Yule's K (text 
characteristics based on George Udny Yule's statistical formula (1994) to calculate the level of difficulty and repetition of words in the text).

Lexical Variation $(\mathrm{VL})=$ token type ratio $\mathrm{x} 100$

Lexical flash $(\mathrm{KL})=$ ratio of lexical token type $\mathrm{x} 100$

Yule's $\mathrm{K}=$ statistical formula in the SCP program

\section{Discussion}

Appraisal systems are realized by means of networking systems to display paradigmatic relationships, paradigmatic relationships are traditionally displayed in paradigms that describe one dimension to another. The first factor relates to the objective Apraisal network system because it has rules based on French grammar where to capture vocabulary that is often used by French students in writing French theses using the Simple Concordance Program (SCP)

From the analysis of the Apraisal System contained in 2 French Thesis texts, the following findings were obtained:

(1). The Apraisal System in the French Thesis at UNIMED is a Paradigmatic System because the Apraisal System in the French thesis text consists of (a). Gender (le genre), which consists of: masculine (masculin) and feminine (féminin) and (b). Total (le nombre), which consists of: single (singulier) and plural (pluriel). The apraisal structure is syntagmatic.

\section{a. Texts 1 and 6}

1) Different leksis, important, petit (small), and heureux (happy) which are adjectives in French cannot stand alone because they must be supported by the auxiliary verb etre. The use of adjectives in French must be adapted to le genre et le nombre (gender and number) of nouns.

Example:

a. La langue possède un rôle important dans la vie humaine

(The language plays an important role in human life)

b. Une considération importante dans lignense

(An important consideration in teaching ...)

2) important lexis in the example clause 1.a. single male because it is adapted to the noun rôle single masculin, while in the example clause 1.b. a single feminine sex because it is adjusted by the feminine noun considération so that the important lexical form turns into important (there is the addition of the letter "e" behind the important lexis.

3) Leksis un appareil, un système, le français, une entité are nouns. The structure of grammar in French l'Aauxiliaire "être" (auxiliary verbs) in French is followed by adjectives, nouns, professions, religion and status. But in the example sentences 5, 6, 7 and 8 it is not an element of Afek in evaluative language because the four lexis do not reveal the situation.

4) Leksis Être

$\hat{E}$ tre (Is)

$\begin{array}{ll}\text { Je suis } & (\mathrm{I} \text { am....) } \\ \text { Tu es } & (\text { You are...) } \\ \text { Il/Elle est } & \text { (She/ He is ...) } \\ \text { Nous sommes } & \text { (We are...) } \\ \text { Vous êtes } & (\text { You are...) }\end{array}$


Ils/Elles sont $\quad$ (They are...)

$\hat{E} t r e+\quad \begin{cases}\text { Nom (Noun) } \\ \text { Adjectif (Adjective) } \\ \text { Réligion (Religion) } \\ \text { Profession (profession) } \\ \text { Statut (status) }\end{cases}$

Leksis être (is, is) is an auxiliaire (auxiliary verb). The conjugations are tailored to the subject. Leksis est conjugation for third-person singular or singular nouns (il / elle).

5) Leksis bien (good), important (important), convenable (appropriate), certain (certain), identique (similar), synonyme (equality of meaning), are adjectives (adjectives) generally located before / in front of nouns. The use of adjectives is adapted to le genre et le nombre (gender and number) of nouns.

6) Leksis bien (good) is a lexis included in evaluative language which is a resource to appreciate the value of an object. Leksis bien (good) is an adjective (noun) for masculine and feminine nouns of the singular and plural.

The phenomenon that the authors found in lexis bien in the example sentence above is not an Afek element in evaluative language. The lexis bien que in the French grammar structure is not an adjective because leksis bien has been followed by the conjunctions que being (bien que (so) + Subjonctif (verb mode expressing doubts) so that the word class differs into conjonction.

voir et regarder aussi, bienqu'ils soient synonyme,

Par conséquent, voir et regarder aussi, bien qu'ils soient synonyme

(Therefore, the verbs of seeing and watching are synonyms)

7) Différent lexis are adjectives generally located before / in front of nouns. The use of différent adjectives is adjusted to le genre et le nombre (sex and number) of nouns so différent lexis (ms) becomes différente (fs). Différence lexis are nouns whose formation of the adjective différent is not an Afek element in evaluative language.

synonyme, bien sûr il y a des differences de sens.

bien sûr il y a des differences de sens.

(of course there are differences in meaning).

8) Pouvoir lexis (can), falloir (must) and vouloir (want, want) are lexical modalities that have a meaning that is realized to express a positive attitude, as contained in clauses 1 , 2, 3 below.

\section{La compositiondesens peut être analysés}

(meaning formation can be analyzed)

2. C'est pourquoi il faut qu'on sache utiliser quel est le mot convenable à quelle situation

(why must know the use of words that fit the situation)

3. qui veulents avoir lexpansion du vocabulaire français

(who want to know the expansion of French vocabulary) 
9) Lexis vouloir, pouvoir, falloir, savoir

$\begin{aligned} & \text { vouloir } \\ & \text { pouvoir } \\ & \text { falloir }\end{aligned}+$
nom (noun)

Vouloir lexis, pouvoir, falloir (want, able, must) are lexical modalities that have a meaning that is realized to express attitudes, views, considerations, opinions of the author of his experience. In French lexis vouloir, pouvoir, falloir are irregular thirdclass verbs, the verb conjugations are adjusted to subject.

Pouvoir lexis is a modality lexis which has a meaning which is realized to express a negative attitude.

10) Un lexis and unité have different meanings and different word classes, $\boldsymbol{U n}$ lexis is an article indefinite, whereas lexis unité is a feminine noun.

La langue possède un rôle important dans la vie

(the language has an important role in life)

la plus petite unité dans le lexique

(a smaller units in lexical)

\section{Conclusion}

An analysis of the Apraisal in the French thesis text at UNIMED shows that the French thesis text illustrates the attitude, stance and judgment in the text and context through evaluative language. In this study the French thesis text was analyzed in three subsystems, namely Attitude, Positioning and Graduation. From the Apraisal analysis on the French thesis text at UNIMED the following conclusions can be drawn:

The Apraisal System in the French Thesis at UNIMED is a Paradigmatic System because the Apraisal System in the French thesis text consists of (a). Gender (le gendre), which consists of: masculine (masculin) and feminine (féminin) and (b). Total (le nombre), which consists of: single (singulier) and plural (pluriel). The apraisal structure is syntagmatic.

\section{References}

Aikhenvald, Alexandra Y. 2004. Evidentiality. Oxford: Oxford University Press.

Bednarek, Monica. 2008. Emotion Talk Across Corpora. London: Palgrave Macmillan.

Besnier, N. 1990. 'Language and affect'. Annual Review of Anthropology 19:59-88.

Bybee, Joan \& Suzanne Fleischman. 1995. Modality in Grammar and Discourse. Philadelphia: Benjamins.

Coates, J. 1983. The Semantics of the Modal Auxiliaries. London: Croom Helm.

Chafe, Wallace. 1986. 'Evidentiality in English Conversation and Academic Writing' dalam Wallace Chafe \& Johanna Nichols. Ed. 1986. Evidentiality: the Linguistics Coding of Epistemology. Norwood, N.J.: Ablex.

Calvet, J et Chompret, C.2010. Grammaire Française. PARIS J. DE GIGORD, EDITEUR Rue Cassette, 15 .

Erwinsah. Solin M, et al. 2019. The Concept of School Literacy Movement Through Reading Time at SDIT Raudaturrahmah Pekanbaru. Birle- Journal. Accessed on March 2020. https://bircu-journal.com/index.php/birle/article/view/204/pdf 
Evianty, Rina. Sari, Risnovati. and Reza, Muhammad. 2020. Developing Student's German Language Competencies through Pragmatic Approach in the Classroom for Higher Education. Birle-Journal. Accessed on March 2020. https://bircu-journal.com/index.php/birle/article/view/853/pdf

Johanson, Lars. And Bo. Utas. Ed. 2000. Evidentials. Turkic, Iranian and Neighbouring Languages. Berlin/N ew York: Mouton de Gruyter.

Halliday, M.A.K. and Ruquiya Hasan.1985. Language Context and Text: Aspect of Language in a Social Semiotic Perspective. Victoria : Deak in University Press.

Halliday, M.A.K. 1985/1994. Introduction to Functional Grammar. London: Adward Arnold.

Halliday, M.A.K \& Christian M.I.M. Matthiessen. 2004. Introduction to Fuctional Grammar, Third edition. London: Arnold.

Martin, J.R. 1992. ENGLISH TEXT System and Structure. Amsterdam: John Benjamins Publishing Company.

Martin, J.R. and D. Rose. 2003. Working with Discourse. London: Continuum.

Martin, J.R. 2004. Sense and Sensibility: texturing evaluation. In J. Foley (ed.), Language, Education and Discourse. London: Continuum.

Martin, J.R. and White, P.R.R. 2005. The Language of Evaluation: Appraisal in English. London: Palgrave.

Perkins, M.R. 1983. Modal Expression in English. Norwood, NJ: Able.

Palmer, F.R. 1995. Modality and the English Modals. London: Longman.

Saragih, Amrin. 2006. Materi Perkuliahan: Pendekatan Linguistik Fungsional Sistemik di Universitas Sumatera Utara.

Sinar, Tengku Silvana. 2003. Teori dan Analisis Wacana: Pendekatan Linguistik Sistemik Fungsional. Medan: Pustaka Bangsa Press.

Sinar, Tengku Silvana. 2008. Phrasal and Experiential Realizationin Lecture Discourse: A Systemic Functional Analysis. Medan: Kopertis Wilayah I Sumut NAD.

Sumarsih. 2009. Penggambaran Sikap, Pendirian, Dan Penilaian Dalam Teks Dan Konteks Melalui Bahasa Evaluatif. Disertasi tidak dipublikasikan. Universitas Sumatera Utara.

Sinar, Tengku Silvana. 2012. Teori dan Analisis Wacana: Pendekatan Linguistik Sistemik Fungsional. Medan: Penerbit Mitra.

Suriyadi. 2014. Apraisal Dalam Teks Editorial Surat Kabar Di Medan. Disertasi tidak dipublikasikan. Universitas Negeri Sumatera Utara.

Widdowson, H.G. 2007. Discourse Analysis. Oxford: Oxford University.

Yule, George Udny. 1994. The Statistical Study of Literacy Vocabulary. Cambridge: CUP. 